\title{
BAHAN AJAR ASAM-BASA MENGGUNAKAN KONTEKS BAHAN PENGAWET MAKANAN UNTUK MENGEMBANGKAN LITERASI SAINS SMK JURUSAN TEKNOLOGI PENGOLAHAN HASIL PERTANIAN (TPHP)
}

\author{
Dian Farkhatus Solikha \\ Guru Bidang Studi Kimia SMK Negeri 2 Indramayu \\ farkhatusdian@yahoo.com
}

\begin{abstract}
ABSTRAK
Penelitian ini bertujuan untuk menghasilkan bahan ajar asam-basa menggunakan konteks bahan pengawet makanan yang dapat mengembangkan kemampuan literasi sains siswa SMK jurusan Teknologi Pengolahan Hasil Pertanian (TPHP) serta mengevaluasi kualitas bahan ajar tersebut berdasarkan validasi ahli, pengujian keterbacaan, dan penilaian guru. Penelitian dimulai dengan pembuatan bahan ajar dengan pendekatan STL (Scientific Literacy and Technology) kemudian disempurnakan dengan metode validasi dan pengembangan. Validasi yang digunakan pada penelitian ini meliputi validasi ahli. Selain itu, bahan ajar juga melalui pengujian keterbacaan dan penilaian guru. Hasil penelitian menunjukkan bahwa empat dimensi sains tertuang dalam bahan ajar, nilai CVR dan CVI menunjukkan bahwa bahan ajar sangat sesuai digunakan dalam pembelajaran baik dalam pembelajaran kimia adaptif maupun pembelajaran mata pelajaran produktif TPHP materi bahan tambahan makanan, persentase total keterbacaan 75,3 \% menunjukkan bahwa bahan ajar dapat digunakan untuk siswa SMK Jurusan TPHP karena mudah untuk dipahami dan termasuk bahan ajar yang baik sekali merujuk pada hasil persentase penilaian guru sebesar 98\%. Kekuatan bahan ajar terletak pada aspek visualisasi (kalimat, ukuran huruf, jenis huruf, tampilan gambar) dan aspek ketertarikan siswa dalam mempelajari materi produktif TPHP, sedangkan kelemahan bahan ajar terletak pada aspek ketertarikan siswa dalam mempelajari materi kimia.
\end{abstract}

Kata Kunci: bahan ajar, literasi sains, validasi ahli, pengujian keterbacaan, penilaian guru

\begin{abstract}
This research aim to yielding substance teach acid-base use food preservative's context to develop science literacy for SMK Jurusan Teknologi Pengolahan Hasil Pertanian (TPHP) and evaluate quality of substance teach based on expert validation, examination reading, and teacher assessment. Research started with making substance teach with model STL (Scientific Literacy and Technology) and then completed with method of and development. Validation used at this research cover expert validation. Others, substance teach also through examination reading and teacher assessment. Results of research show that four dimensions of science decanted in substance teach, assess CVR and CVI show that substance teach very according to used in good study in chemical study of adaptif and also productive subject study of additional TPHP substance food preservative., total percentage of reading $75,3 \%$ show that student substance teach applicable to SMK Majors TPHP because easy to to be comprehended and inclusive of substance teach which very well refer at result presentase assessment learn equal to $98 \%$. Strength of substance teach to lay in aspect visualizing ( sentence, size measure letter, letter type, appearance draw) and the student interest aspect in learning productive items of TPHP. While feebleness of substance teach to lay in aspect of interest of student in learning chemical items.
\end{abstract}

Keywords: substance teach, science literacy, validation expert, examination reading, teacher assessment

\section{PENDAHULUAN}

Sekolah Menengah Kejuruan (SMK) mempunyai karakteristik yang berbeda dibandingkan dengan Sekolah Menengah Atas (SMA), perbedaan tersebut terletak pada output atau lulusan yang dihasilkan. Output atau lulusan yang diharapkan di SMK adalah menghasilkan sumber daya manusia yang kompeten di dunia kerja sesuai dengan bidang atau spesialisasi bidang keahlian dari SMK yang bersangkutan.

Sebagaimana yang tercantum dalam Permendiknas No.23 tahun 2006 tentang Standar Kompetensi Lulusan (SKL) untuk satuan pendidikan dasar dan menengah, bahwa Sekolah Menengah Kejuruan (SMK) menyelenggarakan pendidikan yang mempunyai tujuan meningkatkan 
pengetahuan dan keterampilan siswa untuk menyiapkannya menjadi tenaga kerja tingkat menengah yang terampil, terdidik, dan profesional.Selainitu, untukmengembangkan diri sejalan dengan perkembangan ilmu pengetahuan dan teknologi guna menghadapi tantangan global di dunia usaha dan dunia industri.

Semua tujuan tersebut dapat tercapai apabila siswa dapat menerapkan pengetahuan yang mereka dapatkan untuk memecahkan masalah di kehidupan sehari-hari. Literasi sains merupakan modal dasar bagi siswa SMK untuk menghadapi tantangan global dalam dunia usaha dan dunia industri tersebut. Sesuai yang dikemukakan oleh Hayat dan Yusuf (dalam Setiawati, 2013) bahwa literasi sains berkaitan dengan kapasitas siswa dalam memahami informasi proses terjadinya ilmu pengetahuan dan fakta dalam kehidupan sehari-hari dan kaitannya dengan masa yang akan datang, serta kemampuan menerapkan pengetahuan tersebut dalam kehidupan sehari-hari.

Firman (2007) menyatakan bahwa literasi sains merupakan salah satu ranah studi dari PISA (2009). Literasi sains menurut PISA (2009) berkaitan dengan bagaimana siswa dapat menggunakan sains (kemampuan mengidentifikasi isu-isu ilmiah, menjelaskan fenomena ilmiah, dan menggunakan faktafakta ilmiah). Pengertian tersebut didasarkan pada pengetahuan yang harus dimiliki oleh siswa di usia 15 tahun (jenjang usia untuk siswa SLTP kelas IX). Definisi literasi sains menurut PISA 2009 tidak hanya berkaitan dengan kemampuan pengetahuan sains, namun juga berkaitan dengan tiga dimensi besar literasi sains. Tiga dimensi tersebut mencakup konten (pengetahuan), konteks sains, dan proses (kompetensi) sains.

Berdasarkan hasil PISA 2009 diketahui bahwa kemampuan literasi sains siswa Indonesia masih sangat rendah. Literasi sains penting dikembangkan untuk siswa SMK, mengingat lulusan SMK harus mampu menghadapi tantangan global di dunia usaha dan dunia industri sebagai salah satu wujud aspek konteks dalam dimensi literasi sains.

Struktur kurikulum pendidikan kejuruan dalam hal ini Sekolah Menengah Kejuruan (SMK) membagi mata pelajaran ke dalam tiga kelompok, yaitu kelompok normatif, adaptif, dan produktif. Kelompok normatif adalah mata pelajaran yang dialokasikan secara tetap yang meliputi Pendidikan Agama, Pendidikan Kewarganegaraan, Bahasa Indonesia, Pendidikan Jasmani Olahraga dan Kesehatan, dan Seni Budaya. Kelompok adaptif terdiri atas mata pelajaran Bahasa Inggris, Matematika, IPA (Fisika, Kimia, dan Biologi), IPS, Keterampilan Komputer dan Pengelolaan Informasi, dan Kewirausahaan. Kelompok produktif terdiri atas sejumlah mata pelajaran yang dikelompokkan dalam Dasar Kompetensi Kejuruan dan Kompetensi Kejuruan.

Mata pelajaran kimia di SMK merupakan mata pelajaran adaptif atau dapat disebut sebagai mata pelajaran pendukung. Sesuai dengan fungsi tersebut, mata pelajaran kimia seharusnya dapat memberikan kontribusi terhadap pengembangan mata pelajaran produktif. Namun berdasarkan penelitian pendahuluan yang dilakukan oleh Azizah (2013) menyatakan bahwa mata pelajaran kimia belum mampu mengakomodasi kebutuhan penguatan konsep pada mata pelajaran produktif. Pemaparan ini menunjukkan bahwa pembelajaran kimia yang dilakukan selama ini kurang bermakna bagi siswa SMK. Pada kenyataannya, kimia sangat diperlukan dalam mengembangkan kompetensi keahlian SMK Jurusan TPHP diantaranya dapat menunjang kepada kompetensi mengidentifikasi komoditas dan produk pangan, memahami kaitan mutu dengan produk, mengolah bahan pangan menjadi berbagai produk pangan, mengemas (packing) produk, dapat membuka usaha di bidang pengolahan pangan, menerapkan 
konsep berproduksi dengan baik (good manufacturing practice), dan mengendalikan keamanan pangan.

Jika mata pelajaran kimia adaptif mampu mengakomodasi kebutuhan mata pelajaran produktif maka pemahaman konsep yang diperoleh siswa akan lebih bermakna, sehingga akan meningkatkan kemampuan literasi sains siswa SMK jurusan TPHP dalam memecahkan permasalahan yang terkait. Kemampuan literasi sains ini perlu dikembangkan bagi siswa SMK jurusan TPHP sebagai kecakapan hidup di dunia kerja sehingga lulusan atau tamatan SMK lebih berkompeten dan mampu berdaya saing secara global (nasional dan internasional).

Pemaparan sebelumnya menyatakan bahwa literasi sains mencakup tiga dimensi yaitu konten (pengetahuan), konteks sains, dan proses (kompetensi) sains. Literasi sains berkaitan dengan bagaimana siswa dapat mengaplikasikan konten (pengetahuan) dalam konteks yang terkait dengan kehidupannya. Berdasarkan analisis standar isi mata pelajaran kimia dan analisis standar isi mata pelajaran produktif TPHP disimpulkan konten yang akan dikembangkan pada penelitian ini adalah konten asambasa. Sementara itu, konteks yang dekat dengan siswa SMK jurusan TPHP dan dapat diakomodasi dengan konten asam-basa yaitu konteks bahan pengawet makanan.

Berdasarkan pemaparan di atas terlihat bahwa materi produktif ternyata dapat diakomodasi dengan materi kimia adaptif, namun diperlukan suatu bahan ajar untuk memvisualisasikannya. Bahan ajar tersebut diharapkan dapat membantu siswa dalam memahami secara utuh materi produktif TPHP dan materi kimia adaptif sehingga pembelajaran kimia adaptif yang dilakukan dapat sinergis dengan produktif TPHP. Perwujudan pengambilan keputusan dari literasi sains terhadap sains dan teknologi adalah Scientific and Technological Literacy
(STL), maka bahan ajar yang dikembangkan mengikuti model Scientific and Technological Literacy (STL).

Beberapa penelitian mengenai bahan ajar yang telah dilakukan diantaranya adalah sebagai berikut: (1) Penggunaan bahan ajar berbasis multimedia interaktif pada tema perubahan iklim untuk meningkatkan literasi sains siswa SMP oleh Windyarni, 2011; dan (2) Pengembangan bahan ajar bermuatan nano untuk mencapai literasi sains siswa melalui model rekonstruksi pendidikan oleh Noer-Azizah, 2013.

Penelitian tersebut memiliki kesamaan dalam ranah pengembangan bahan ajar yang bertujuan untuk mengembangkan literasi sains. Adapun penelitian serupa yang telah dilakukan pada jenjang SMK dilakukan oleh Azizah (2013) mengenai pola pengintegrasian mata pelajaran adaptif kimia di SMK pelayaran. Berdasarkan penelitian tersebut, didapatkan informasi bahwa terdapat banyak mata pelajaran kimia adaptif yang dapat diintegrasikan dengan produktif.

Tujuan yang ingin dicapai dalam penelitian ini adalah 1) menghasilkan bahan ajar asambasa asam-basa menggunakan konteks bahan pengawet makanan yang dapat mengembangkan kemampuan literasi sains siswa SMK Jurusan Teknologi Pengolahan Hasil Pertanian (TPHP) dan 2) mengevaluasi kualitas bahan ajar yang dikembangkan dalam penelitian berdasarkan hasil validasi ahli, tingkat keterbacaan, dan hasil penilaian guru.

\section{METODE PENELITIAN}

Penelitian bahan ajar asam-basa menggunakan konteks bahan pengawet makanan yang dapat mengembangkan literasi sains siswa SMK ini dilakukan dengan metode pengembangan dan validasi. Penelitian diawali dengan mengembangkan bahan ajar mengikuti empat tahapan yaitu 
proses seleksi, proses strukturisasi, proses karakterisasi, dan proses reduksi. Bahan ajar yang dikembangkan mengikuti model STL (Scientific and Technological Literacy (STL). Bahan ajar yang telah dikembangkan kemudian melalui validasi. Validasi yang digunakan pada penelitian ini yaitu validasi ahli (dosen ahli, guru kimia, dan guru produktif TPHP).

Selain menggunakan validasi, bahan ajar ini juga melalui uji coba terbatas keterbacaan dan penilaian oleh guru produktif TPHP dan guru kimia adaptif. Uji coba terbatas keterbacaan bahan ajar dilakukan kepada siswa SMK Jurusan TPHP kelas XII ( 27 orang siswi dan 3 orang siswa). Sedangkan penilaian guru dilakukan oleh guru produktif TPHP dan guru kimia adaptif.

Data yang diperoleh dari penelitian ini berupa data kualitatif dan kuantitatif. Data kuantitatif yang telah terkumpul kemudian dianalisis menggunakan statistika deskriptif. Menurut Sugiono (2008), statistika deskriptif adalah statistik yang digunakan untuk menganalisis data dengan cara mendeskripsikan atau menggambarkan data yang telah terkumpul sebagaimana adanya tanpa bermaksud membuat kesimpulan yang berlaku untuk umum atau generalisasi.

\section{Subjek dan lokasi penelitian}

Subjek dalam penelitian adalah buku ajar yang dikembangkan. Penelitian ini dilakukan di salah satu SMK di Kabupaten Indramayu. SMK tersebut memiliki tujuh jurusan yaitu TPHP (Teknologi Pengolahan Hasil Pertanian), NKPI (Nautika Kapal Penangkapan Ikan), TAB (Teknik Alat Berat), JB (Jasa Boga), AP (Agrobisnis Perikanan), RPL (Rekayasa Perangkat Lunak), dan TKJ (Teknik Komputer Jaringan).

\section{Instrumen}

Instrumen yang digunakan pada penelitian ini berupa instrumen validasi ahli, instrumen keterbacaan bahan ajar,dan penilaian guru.
Berikut ini adalah pemaparan mengenai instrument yang digunakan pada penelitian ini.

Instrumen validasi ahli. Instrumen digunakan untuk menvalidasi bahan ajar yang telah dirancang, sebagai langkah sebelum penyempurnaan bahan ajar. Bahan ajar divalidasi oleh validator yang berjumlah enam orang, yaitu dua orang dosen, dua orang guru kimia, dan dua orang guru produktif TPHP.

Instrumen keterbacaan bahan ajar. Keterbacaan bahan ajar diukur melalui metode rumpang (Cloze Prosedure,), metode ini befungsi untuk mengukur tingkat keterbacaan sebuah wacana dan menggambarkan kemampuan siswa terhadap bahan bacaan. Pada penelitian ini, metode rumpang mengikuti langkah-langkah sebagai berikut :

a. memilih wacana yang berjumlah lebih dari 250 kata.

b. pelesapan kata tidak bergantung pada jarak lesapan atau penghilangan namun bergantung pada jenis kata yang dilesapkan.

c. kata yang dilesapkan atau dihilangkan merupakan konten asam-basa dan konteks bahan pengawet makanan

d. menuliskan angka (1), (2), (3), dan seterusnya pada awal kata yang dihilangkan atau dilesapkan, kemudian mengganti kata yang dilesapkan atau dihilangkan dengan tanda "......"

Instrumen keterbacaan bahan ajar ini ditujukan untuk siswa SMK jurusan TPHP kelas XII yang telah mempelajari materi asam basa (kimia) dan materi bahan tambahan makanan (produktif).

Instrumen Penilaian Guru. Penilaian guru digunakan untuk mengetahui kelayakan bahan ajar berdasarkan aspek visualisasi (kalimat, ukuran huruf, jenis huruf, tampilan gambar), aspek ketertarikan siswa dalam 
mempelajari materi kimia, dan aspek ketertarikan siswa dalam mempelajari materi produktif TPHP (Bahan pengawet makanan). Guru yang menilai bahan ajar pada penelitian ini terdiri dari dua orang guru kimia adaptif dan dua orang guru produktif TPHP. Jumlah pernyataan yang diajukan berjumlah sepuluh buah.

\section{HASIL DAN PEMBAHASAN}

Pembuatbahanajardiawalidenganmelakukan telaah standar isi mata pelajaran kimia untuk memilih konten dan telaah standar isi mata pelajaran produktif TPHP untuk memilih konteks. Setelah melakukan telaah standar isi tersebut, peneliti menentukan asam-basa sebagai konten dan bahan pengawet makanan sebagai konteks. Bahan ajar kemudian dibuat melalui beberapa tahapan yaitu proses seleksi, proses strukturisasi, proses karakterisasi dan proses reduksi hingga didapatkan teks dasar.

Tahap pertama setelah penentuan konten asam basa dan konteks bahan pengawet makanan maka dilakukan proses seleksi. Proses seleksi yang dilakukan harus memenuhi kriteria kebenaran secara keilmuan baik pada konten asam-basa dan konteks bahan pengawet makanan, keluasan dan kedalaman materi yang disesuaikan dengan siswa SMK Jurusan TPHP, perkembangan psikologis dan berfikir siswa SMK Jurusan TPHP, manfaat bagi siswa SMK Jurusan TPHP sehingga bahan ajar yang diberikan lebih bermakna, ketersediaan waktu yang disediakan oleh kurikulum untuk menyampaikan bahan ajar yang akan dibuat dan aspek keesensialan konsep (konten asam basa dan konteks bahan pengawet makanan). Proses seleksi ini bertujuan untuk mendapatkan bahan ajar yang sesuai dengan kebutuhan siswa SMK Jurusan TPHP. Proses seleksi untuk konten asan-basa dilakukan dengan menganalisis empat buah buku teks (lampiran 1.1), sedangkan untuk konteks bahan pengawet makanan dilakukan seleksi pada teks bahan pengawet makanan dan referensi lainnya yang berkaitan dengan bahan pengawet makanan (lampiran 1.5).

Tahap kedua, setelah dilakukan proses seleksi maka dilakukan proses strukturisasi. Proses strukturisasi bertujuan agar bahan ajar yang dibuat tidak mengandung konsep yang parsial. Selain itu poses strukturisasi bertujuan untuk memberikan kesesuaian antara kebutuhan siswa SMK Jurusan TPHP dengan isi bahan ajar tersebut. Proses strukturisasi ini dilakukan pada teks konten asam-basa dan teks konteks bahan pengawet makanan. Proses strukurisasi ini menghasilkan teks gabungan konten asambasa dan teks gabungan konteks bahan pengawet makanan.

Tahap ketiga kemudian melalui proses karakterisasi menjadi abstrak, kompleks, dan rumit (lampiran 1.2) agar memudahkan dalam membuat bahan ajar yang sesuai dengan karakteristik siswa SMK jurusan TPHP. Ketentuan karakterisasi tersebut adalah teks bersifat abstrak apabila teks tidak bersifat konkret, kompleks apabila teks tidak bersifat simple, dan rumit apabila teks tidak bersifat sederhana. Setelah dilakukan karakterisasi kemudian dilakukan reduksi.

Tahap keempat kemudian melalui proses reduksi. Pada proses ini bahan ajar direduksi secara didaktis, dengan pertimbangan aspek psikologis dan keilmuan, agar bahan ajar yang telah mengalami reduksi ini dapat difahami oleh siswa SMK Jurusan TPHP dengan mudah. Pada proses reduksi dihasilkan bahan ajar yang siap untuk divalidasi oleh ahli.

Dimensi literasi sains. Empat dimensi sains yaitu aspek konteks aplikasi sains (konteks) berupa pemilihan makanan (bahan pengawet makanan), aspek proses (kompetensi) sains berupa mengidentifikasi pertanyaan ilmiah dan menjelaskan fenomena secara ilmiah, aspek pengetahuan (konten) berupa asam basa yang mengarah pada hubungan sains dengan teknologi dan aspek sikap sains berupa mendukung inkuiri ilmiah, percaya 
diri sebagai pembelajar sains, ketertarikan terhadap sains, dan tanggung jawab terhadap diri dan lingkungan.yang tertuang dalam bahan ajar asam-basa menggunakan konteks bahan pengawet makanan melalui tujuan pembelajarannya.

Validitas bahan ajar. Hasil perhitungan CVI $(0,99)$ menunjukkan bahwa materi konten dan konteks yang terdapat pada bahan ajar sangat sesuai, konteks dan konten sangat sesuai dengan tujuan pembelajaran, materi sangat sesuai dengan tahapan STL, penggunaan gambar, ilustrasi, simbol, dan percobaan sesuai untuk bahan ajar, dan materi pada bahan ajar sangat sesuai dengan kemampuan siswa SMK. Allahyari,et all (2010) menyatakan bahwa untuk jumlah responden enam orang maka nilai minimum untuk CVI diterima adalah 0,99. Berdasarkan hasil perhitungan validasi ahli didapatkan nilai CVI 0,99 maka sesuai dengan nilai minimum nilai CVI untuk diterima maka bahan ajar dikatakan sangat sesuai pada setiap aspek kesesuaian.

Hasil perhitungan CVI menunjukan bahwa materi konten dan konteks yang terdapat pada bahan ajar sangat sesuai, konteks dan konten sangat sesuai dengan tujuan pembelajaran, materi sangat sesuai dengan tahapan STL, penggunaan gambar, ilustrasi, simbol, dan percobaan sesuai untuk bahan ajar, dan materi pada bahan ajar sangat sesuai dengan kemampuan siswa SMK.

Rata-rata CVI yang diperoleh untuk bahan ajar asam-basa menggunakan konteks bahan pengawet makanan yang dapat mengembangkan literasi sains SMK Jurusan Teknologi Pengolahan Hasil Pertanian (TPHP) adalah sebesar 0,99. Berdasarkan kategori nilai CVI maka bahan ajar asambasa menggunakan konteks bahan pengawet makanan yang dapat mengembangkan literasi sains SMK Jurusan Teknologi Pengolahan Hasil Pertanian (TPHP) sangat sesuai untuk digunakan dalam pembelajaran baik dalam pembelajaran kimia adaptif maupun pembelajaran mata pelajaran produktif TPHP materi bahan tambahan makanan.

Keterbacaan bahan ajar. Terdapat tiga orang siswa yang hanya mampu menjawab kurang dari 50\%, selebihnya dapat menjawab dengan benar lebih dari 50\%. Tiga orang siswa yang hanya mampu menjawab kurang dari 50\% (tepatnya hanya 25\%), melihat prestasi di kelas temasuk siswa yang kurang pandai dan siswa yang kehadirannya pun kurang. Berdasarkan data pendukung tersebut maka dapat dinyatakan bahwa agar dapat menjawab dengan benar kata yang dilesapkan atau dihilangkan maka siswa harus paham akan konten asam-basa dan konteks bahan pengawet makanan. Persentase (\%) total keterbacaan bahan ajar menunjukkan 75,3\% siswa mampu menjawab dengan benar kata yang dilesapkan atau dihilangkan. Merujuk pada kategorisasi tafsiran sebaran siswa menurut Koentjoroningrat, maka presentase (\%) total $75,3 \%$ menyatakan bahwa sebagian besar siswa SMK Jurusan TPHP kelas XII mampu menjawab dengan benar pada tes ketebacaan bahan ajar menggunakan metode rumpang.

Menurut Schlezinger (dalam Hardjasujana, 1996), persentase hasil tes rumpang sebesar $75,3 \%$ diinterpretasikan bahwa kata yang dilesapkan atau dihilangkan tergolong mudah, sedangkan sebesar $24,7 \%$ diinterpretasikan bahwa kata yang dilesapkan atau dihilangkan tergolong sukar. Berdasarkan interpretasi tesebut maka dapat dikatakan bahwa bahan ajar asam-basa menggunakan konteks bahan pengawet makanan yang dibuat pada penelitian ini dapat digunakan untuk siswa SMK Jurusan TPHP karena mudah untuk dipahami. Penggunaan bahan ajar ini diharapkan dapat memudahkan siswa untuk memahami konten asam basa dan konteks bahan pengawet makanan, sehingga pembelajaran kimia dapat mengakomodasi pemahaman konsep pada produktif TPHP. 
Sebagaimana yang dikemukakan pada bab II yaitu bahan ajar merupakan sarana belajar yang penting untuk siswa mencapai kompetensi secara runtut dan sistematis sesuai dengan kebutuhan peserta didik.

Penilaian guru. Secara rinci sebanyak $100 \%$ guru menilai bahan ajar asam basa menggunakan konteks bahan pengawet makanan termasuk bahan ajar yang baik sekali dilihat dari ukuran dan jenis huruf yang tampilan gambar, pemanfaat space, dan aspek ketertarikan siswa dalam mempelajari materi produktif TPHP (Bahan pengawet makanan).

Kekuatan bahan ajar asam basa menggunakan konteks bahan pengawet makanan menurut penilaian guru kimia adaptif dan guru produktifTPHP terletak pada aspek visualisasi (kalimat, ukuran huruf, jenis huruf, tampilan gambar) dan aspek ketertarikan siswa dalam mempelajari materi produktif TPHP (Bahan pengawet makanan). Kelemahan bahan ajar asam basa menggunakan konteks bahan pengawet makanan menurut penilaian guru kimia adaptif dan guru produktif TPHP terletak pada aspek ketertarikan siswa dalam mempelajari materi kimia.

\section{KESIMPULAN}

Empat dimensi sains yaitu aspek konteks aplikasi sains (konteks) berupa pemilihan makanan (bahan pengawet makanan), aspek proses (kompetensi) sains berupa mengidentifikasi pertanyaan ilmiah dan menjelaskan fenomena secara ilmiah, aspek pengetahuan (konten) berupa asam basa yang mengarah pada hubungan sains dengan teknologi dan aspek sikap sains berupa mendukung inkuiri ilmiah, percaya diri sebagai pembelajar sains, ketertarikan terhadap sains, dan tanggung jawab terhadap diri dan lingkungan.yang tertuang dalam bahan ajar asam-basa menggunakan konteks bahan pengawet makanan melalui tujuan pembelajarannya.
Nilai CVR dan CVI menunjukkan bahwa bahan ajar asam-basa menggunakan konteks bahan pengawet makanan yang dapat mengembangkan literasi sains SMK Jurusan Teknologi Pengolahan Hasil Pertanian (TPHP) sangat sesuai (berkualitas) untuk digunakan dalam pembelajaran baik dalam pembelajaran kimia adaptif maupun pembelajaran mata pelajaran produktif TPHP materi bahan tambahan makanan.

Persentase (\%) total keterbacaan bahan ajar menunjukkan $75,3 \%$ siswa mampu menjawab dengan benar kata yang dilesapkan atau dihilangkan. Merujuk pada kategorisasi tafsiran sebaran siswa menurut Koentjoroningrat, maka persentase (\%) total $75,3 \%$ menyatakan bahwa sebagian besar siswa SMK Jurusan TPHP kelas XII mampu menjawab dengan benar pada tes ketebacaan bahan ajar menggunakan metode rumpang. Menurut Schlezinger (dalam Hardjasujana, 1996), persentase hasil tes rumpang sebesar $75,3 \%$ diinterpretasikan bahwa kata yang dilesapkan atau dihilangkan tergolong mudah. Berdasarkan interpretasi tesebut maka dapat dikatakan bahwa bahan ajar asambasa menggunakan konteks bahan pengawet makanan yang dibuat pada penelitian ini dapat digunakan untuk siswa SMK Jurusan TPHP karena mudah untuk dipahami.

Bahan ajar asam basa menggunakan konteks bahan pengawet makanan yang dibuat pada penelitian ini termasuk bahan ajar yang baik sekali Arikunto (2006), merujuk pada hasil presentase penilaian guru sebesar 98\%. Kekuatan terletak pada aspek visualisasi (kalimat, ukuran huruf, jenis huruf, tampilan gambar) dan aspek ketertarikan siswa dalam mempelajari materi produktif TPHP (Bahan pengawet makanan), sedangkan kelemahan bahan ajar terletak pada aspek ketertarikan siswa dalam mempelajari materi kimia. 


\section{DAFTAR PUSTAKA}

Alami, Sarinur Fitri. (2012). Penerapan Model Pembelajaran STM dalam Pokok Bahasan Kalor untuk Meningkatan Penguasaan Konsep dan Literasi Sains Siswa SMA. Tesis Magister pada Pascasarjana UPI Bandung : Tidak Diterbitkan.

Arifin, Mulyati, dkk. (2003). Strategi Belajar Mengajar Kimia. Bandung: Jurusan Pendidikan Kimia FPMIPA UPI.

Arikunto, Suharsimi.(2006). Prosedur Penelitian. Jakarta: PT Rineka Cipta.

Arikunto, Suharsimi.(2007). Dasar-Dasar Evaluasi Pendidikan. Jakarta : Bumi Aksara.

Azizah, Dewiantika. (2013). Pola Pengintegrasian Mata Pelajaran Adaptif Kimia di SMK Pelayaran. Tesis Magister pada Pascasarjana UPI Bandung : Tidak Diterbitkan.

BSNP. (2006). Permendiknas No.22 Tahun 2006 Tentang Standar Kompetensi Lulusan untuk Satuan Pendidikan Dasar Dan Menengah. Jakarta : Depdiknas.

Bybee, Roger. (2009).Program for International Student Assessment (PISA) 2006 and Scientific Literacy: A Perspective For Science Education Leaders. Vol.18, No.2

Brenntag Food \& Nutrition Europe.(2011). Food \& Beverage Preservation. Germany.

Chang, Raymond .(2006). Chemistry.U.S : Pearson

Dahar, R. W. (1996). Teori-Teori Belajar. Jakarta: Erlangga

DeBoer, Gorge. (2000). Scientific Literacy: Another Look at Its Historical and Contemporary Meanings and Its Relationship to Science Education Reform. Journal Of Research In Science Teaching Vol. 37, No. 6, PP. 582601.

Departemen Pendidikan Nasional. (2008). Pedoman Pembuatan Bahan Ajar. Jakarta: Depdiknas

Dillon, Justin. (2009). On Scientific Literacy and Curriculum Reform. International Journal of Environmental \& Science Education Vol 4, No. 3, 201-203.

Dweck,Anthony C.(2010). Natural Preservatives.UK: Peter Black Medicare Ltd

Fernandez, I.Y. 2002. "Pembelajaran Bahasa Indonesia Menuju Sebuah Pendekatan yang Sesuai" dalam Telaah Bahasa dan Sastra. Jakarta: Yayasan Obor Indonesia.

Firman, H. (2007) Analisis Literasi Sains Berdasarkan
Hasil PISA Nasional Tahun 2006. Jakarta : Puspendik.

FHSST.(2008). Textbooks for High School Students Studying the Sciences Chemistry Grades 10 -12 . FSSHT

Hardjasujana, Ahmad S. dan Yeti Mulyati. 1996. Membaca 2. Jakarta: Depdikbud.

Hoolbork.(1998). A resource book for teachers of Science subjects. Europe: UNESCO

Karen C. (2012). Chemistry An Introduction to General, Organic, and Biological Chemistry- 11ed edition.Canada : Pearson

Koentjoroningrat.(1985). Metode Penelitian untuk Masyarakat. Jakarta : Gramedia.

Lawshe, C.H. (1975). A Quantitative Approach to Content Validity. Personel Pyshycology. 28, 563-575.

Noer-Azizah, Retzy. (2013). Pengembangan Bahan Ajar Bermuatan Nano untuk Mencapai Literasi Sains Siswa Melalui Model Rekonstruksi Pendidikan. Tesis Magister pada Pascasarjana UPI Bandung : Tidak Diterbitkan.

OECD. (2007). Executive Summary PISA 2006: Science Competencies for Tomorrow's World. .USA : OECD-PISA.

OECD. (2009). PISA2009 Assessment Framwork: Key Competencies in Reading, Mathematics, and Sciene.USA : OECD-PISA.

Petruci Ralph.(2010).General Chemistry Principles and Modern Applications Tenth Edition. Canada : Pearson

Putrayasa, I.B. 2001. Penerapan Model Inkuiri dalam Pembelajaran Bahasa Indonesia. Disertasi. Bandung: UPI Bandung.

Sanjaya, Wina. (2006). Strategi Pembelajaran. Jakarta : Kencana Prenada Media Group

Setiadi, Rahmat. (1995).Studi Penerapan Pedagogi Materi-Subyek dalam Penulisan Buku Teks MIPA untuk Mengembangkan Keterampilan Intelektual Mahasiswa FPMIPA IKIP Bandung. Laporan Penelitian. Bandung : Tidak diterbitkan.

Setiawati, Dwi Murni. (2013). Analisis Literasi Sains Guru Biologi SMA dan Penerapannya dalam Proses Mengembangkan LKS Inkuiri. Tesis Magister pada Pascasarjana UPI Bandung : Tidak Diterbitkan. 